\title{
Müsâhiplik: An Anthropological Analysis on Fictive Kinship of Alevis in Turkey ${ }^{i}$
}

\author{
Hiroki Wakamatsu \\ Faculty of Economics, Management and Social Sciences, Toros University, Turkey
}

Received April 10, 2019; Revised May 30, 2019; Accepted June 14, 2019

Copyright $\subseteq 2019$ by authors, all rights reserved. Authors agree that this article remains permanently open access under the terms of the Creative Commons Attribution License 4.0 International License

\begin{abstract}
Müsahiplik is the tradition of fictive kinship which has long been practiced within both Turkish and Kurdish Alevi communities in Turkey. Müsahip is a special term which means blood brother used in Alevi community. The tradition of Müsahiplik may be defined as a religious fraternity between two men who are not relatives. And at the same time, if these two men marry their wives also have relation of Müsahip. The fraternity is dedicated to a religious authority called Dede. It is an institution of social characteristic that is proper for originated from nomad or semi-nomad societies and of recent urban settlement. This custom is one of the most important religious practices of Alevis in Turkey. In a ceremony in the presence of a Dede, the two couples make a life-long commitment to care for the spiritual, emotional, and physical needs of each other and their children. The ties between couples who have made this commitment are at least as strong as it is for blood relatives. So much so, that Müsahiplik is often called spiritual brotherhood (manevi kardeşlik). In this article, drawing on my own research data, I shall first discuss how the Müsahiplik is practiced in the field in Turkey, and provide a brief outline of their meaning in Alevi theology. I shall then present the current situation of Müsahiplik and popular beliefs and discuss the underlying motives of the religious actors involved. Finally, I shall contextualize these cases within a broader theoretical and comparative perspective on fictive kinship from the point of view of Cultural Anthropology.
\end{abstract}

Keywords Alevism-Bektashism, Müsahiplik, Fictive Kinship, Cultural Anthropology

\section{Introduction}

The recent proliferation of television, radio, periodicals, and internet has provided a habitat for the evolution of native intellectuals. Through these media outlets, "organic" intellectuals become pivotal in identity-seeking movements. Broad and long-term shifts from an oral to a print culture, based on the spread of mass education, diminish the significance of traditional religious scholars (Ulema for Sunni Muslims, dede for Alevis) in favor of urbanized intellectuals better adjusted to new media outlets. Local mechanisms of socialization through neighborhood Qur'anic seminaries or dede-based teaching have gradually lost their authority, leading to searches for new ways of building authority to challenge, articulate, and participate in the formation of identities and ideas on a national scale. The new communications networks promote such shifts in the production and control of knowledge by offering new avenues for the introduction of more abstract and flexible frames of reference to cope with the evolving socio-political landscape. Identity makers, cultural entrepreneurs, and opinion makers all struggle to carve out a space for themselves in these new media by bringing sensitive issues into the public debate [1].

Alevilik bir sir değildir "Alevism is no secret" declares an Alevi religious leader in the title of one of his recent books (Celasun 1993). Some twenty years ago such a statement would hardly have come to the minds of those who were neither expert in the field nor Alevi religious authorities. Only now and then had Alevism or Bektashism been taken up publicly during republican times, and if ever, Turkish nationalism seemed to be the actual issue. They were always quite instrumentalist approaches, rather than serious attempts to keynote the substance of Alevi faith, rituals and morals. The statement cited indicates that in Turkey of our days some things have changed fundamentally: According to the official ideology the ethnic and religious heterogeneity of Turkey's population had for long been evaded as a topic, or even denied in public. Then, in the second half of the eighties, taboos that had restricted the discourse so far were broken. Suddenly Alevism appeared on the public agenda. Alevi and Bektashi started to reflect openly on the doctrines and ritual practices of their once esoteric religion - a transgression 
that would in former times have incurred the penalty of exclusion from the community. By way of contrast Alevism is nowadays no longer something mysterious, "Alevi reality" can no longer be avoided in Turkey's social and political life, even if the enthusiasm that set the Alevi community into motion in the early nineties and which brought the topic to the fore has somewhat abated. The discussion on Alevism appears in countless publications. Prior to this, one can observe a scientific interest in Bektashism in particular for nearly a hundred years [2].

The Alevis consist of sizable proportion of the Republic's population - it is not clear exactly how great for the census does not ask detailed religious affiliation. Nevertheless, one may suppose that there are between ten and fifteen million Alevis in Turkey today. The question of the absolute number of Alevis in Turkey is extremely difficult, because there are so many claims and counter-claims. Based partly on David Shankland's detailed research of one particular area and partly on general (though of course much more limited) experience of Turkey as a whole, his own thought is that the vast majority of popular claims, which may suggest that the Alevis are up to 30 per cent of Turkey's population, are exaggerated. It is perhaps overlooked that there are great regions of Turkey where there are no Alevis at all, such as Konya, or very few, such as the provinces of the Black Sea Coast, which would more than make up for other areas (such as Amasya for example) where they are more numerous. Of course, until a reliable survey has been conducted, all such Turkey's population (in the region of 70 millions), even if the figure does turn out to be nearer 15 per cent, that would still mean that there are nine million Alevis in the Republic, a mass easily large enough to be of highly significant social and political importance [3]. Both Kurdish and Turkish in terms of ethnic background, they are from the religious point of view markedly "heterodox". They emphasize Ali within their ritual obeisance, and are markedly mystical in their interpretation of Islam's creed [4].

In the past, the difference of religious approach has often led the Alevis to be persecuted by Sunnis. The situation is more complicated however, in that whereas only a proportion of the Sunni population were persuaded by the Republic secular reforms, the vast majority of the Alevi population support them strongly. In part this is because they appear to offer the possibility of full citizenship without discrimination by religion. In part though, the way that the Alevi understanding of religion has adopted and changed parallels the Republican reformulation of Islam. In other words, they have been prepared to internalize their faith, to regard religion as primarily a question of private moral values, and are not at all interested in reorganizing society along the lines of a religious model.

The Alevis are traditionally almost entirely rural. In a rapidly modernizing Anatolia, they do not appear to have created their own centres. With the sole exception perhaps of Hacıbektaş, a small town in the central Anatolia, which many Alevis regard as the resting place of their founding saint, they in no case form the majority of the inhabitants of a town (and even in that case they do not form the majority of the government officials within the town). Instead, they form sub-sections of the larger towns dominated by the Sunni form of mosque-worship, living in their own distinct parts of the community, in often rather uneasy relationship with the rest of the town [5].

In this situation, when people begin to try to answer against questions such "what is Alevism?" or "who are the Alevis?" a lot of discourse and controversy concerning the Alevis or Alevism appears in Turkish society. For instance, among these questions we can find a question like "Are Alevis Muslim?", "Why don't Alevis fast in Ramadan?", and "Why do Alevis ignore five times prayer per a day?" These questions and answers have been revealed on the internet websites made by various Alevi and non-Alevi intellectuals. Even Alevi religious authorities called dede dispute about Alevi ritual practices and Alevism itself. When I stayed in my field to investigate research concerning the Alevism, I usually observed that people discuss what Alevism is. Among these discussions Alevi people themselves wander "what is Müsahiplik?" or "who are Müsahip?"

A lot of articles and books have been published by especially Alevi cultural associations concerning Müsahiplik tradition (or practice). We are able to access easily to these sources written in Turkish. One of the most famous sources is Kaygusuz's book titled "Müsahiplik". According to him, Müsahiplik means the brotherhood of religious path. Then the Müsahip means those who are brother on the same religious way. At the same time these müsahips must not be relatives and have any blood kinship relations. This relationship is connected just only one time during his/her life. If the relationship has to be canceled, either one müsahip must be died. If one müsahip marries, the other müsahip must also marry. At the same time, their spouses become müsahip with each other. So when two men decided to be müsahip, they have to scarcely choose them. Their spouses have to get along well with each other. Then their children are considered as their fictive children with each other. To be müsahip their education level must be same [6].

Condition and provision to be müsahip traditionally are practiced and applied to disciples by Alevi religious leader called dedes. Müsahiplik had so important meaning to make a connection with outside the Alevi community like bringing into connection among Alevi communities where the people generally get up to marry with their relatives. However, basic understanding of Müsahiplik shared as common sense among the Alevis often involves Alevi people living in the process of huge social change like globalization with impossibility to live. For instance, especially people in Eastern Anatolia are obliged to be müsahip with their relatives due to the problems derived 
from instability and disagreement like terror although müsahip must be out of relatives with blood tie. It is very ideal that an Alevi in Çorum (West Anatolia) can be müsahip with an Alevi in Tunceli (East Anatolia) theoretically. However, we can say that this case is very rare in the actual field. As Kehl-Bodrogi mentions that one of the most important requirement to be an Alevi is to have a müsahip along with being an Alevi who is dependent on affinity as Alevi lineage [7].

\section{Müsahiplik of Alevism-Bektashism and Methodology}

\subsection{General Understanding of Müsahiplik in Alevi-Bektashi Tradition}

According to Mélikoff, müsahiplik is on the other word "the brotherhood of afterlife". She explains that the concept of müsahiplik is very flexible and ambiguous. Müsahips take care of each other more than blood brothers.

Müsâhiplik has been used as a sense of "social brotherhood" or "blood via affinity" in the Alevi-Bektashi tradition for a long time outside of an actual blood kinship (akrabalık). A sense of kinship takes mandatory blood kinship, while this type of relationship is purely voluntary-based on akrabalık. Müsâhiplik is a relationship between two men who are not relatives. To be a relation of Müsâhip, two men must be good friends and at the same time they must not have any blood ties. If they are married, their wives become Müsahip too [8].

It can be defined as two men (and their wives) with no blood tie are blessed by a dede and made as spiritual brother. The custom of Müsahip is one of the seven obligations for an Alevi. A person with no Müsahip cannot attend cem ceremony especially görgü cem. A person who cannot attend cem cannot enter the path [9].

Although to be an Alevi, it is sufficient to be born Alevi father and mother, the individuals can be Müsahip with other married couple and attend the gathering (I $k r a \hat{r}$ ). Hence they ascend from a natural membership to official membership of the community. Every Alevi couple must keep a Müsahip. These two families of four members form the core for Alevi society and are considered as siblings to each other. This brotherhood is the brotherhood of both for the world and for the Hereafter. If a man from one of the sides and man from the other side among the Müsahip die, the two surviving man and woman cannot get married too. The Müsahiplik men are called "brothers" while women are called "sisters". Except their honor and possessions, almost all their belongings are shared. If they are bankrupt, their animals die, their products are damaged, and their Müsahips immediately come to help. The Müsahip, who comes for help, gives some possessions, help financially and provides food to the one in need depending on his power. The children of Müsahip cannot get married to each other. Such a situation demonstrates how long established is Müsahip brotherhood [10].

While they can marry with their uncle's children or aunt's children with each other, they can never marry with müsahip's children with each other. It is the fact that their children are regarded as "brother" and "sister" in their community. Among the müsahips, it can be found that there are both the way of religious brotherhood and the way of social brotherhood.

Every married man has to choose a companion (müsahip). The obligations binding two couples to provide support and assume responsibility for the others are the same as marriage obligations, and continue after the death of one of the partners, extending to their offspring. This institution is specific to the Kizilbas/Alevis but is not found in all groups.

Original source of the tradition of Müsahiplik is depended on the oral tradition of Pir Sultan Abdal's nefes (blessing/poem) derived from Alevi-Bektashi tradition.
Ĕger farz içinde farzi sorarsan
Yine farz içinde farz dir musâhip
Dört kapidan kirk makamdan ararsan
Yine farz içinde farz dir musâhip

Musâhipsiz kişi cem'e gelür mü?

Ettiği niyazlar kabul olür mü?

Muhammed Ali yolundan derman bulür mü?

Yine farz içinde farz dir musâhip. [11]

If you ask whether müsahiplik is one of the important religious obligations or not

The answer is yes; it is true yet.

If you seek the four doors and forty posts,

Yet müsahiplik is one of the important religious obligations.

Can believers without müsahip enter into cem ceremony?

Can their supplication be accepted by the Truth?

Can belivers find the energy from the Way of Muhammed-Ali?

Yet müsahiplik is one of the important religious obligations.

As I show you above, müsahiplik tradition is one of the important religious traditions for Alevi people even though the tradition has been narrated from an oral tradition. On the other word, it means without müsahiplik Alevi people cannot be Alevi according to the Alevi tradition. In Alevi Bektashi tradition müsahiplik is characterized as one of the important religious obligations. In fact, as mentioned by the commandment of Imam Ja' far Al-Sadik, it is qualified as the concept of dört kapı kırk makam (four doors and forty posts) [12]

Even Shah Ismail Hatayi who is founder of Safavid Empire and is accepted as Pir [13] by Alevi-Kızılbaş people mentioned that the people have to make 
müsahiplik relationship to accomplish the Way to Allah as shown below [14].

Kâmil olur Kâmil sözüne uyan
Ol kerem kânidir şol yolu koyan
O Hakk'ın gününde yerini bulan
Musahibsiz asla özün bulamaz

Musahib olunca özünü bulur

Kahrl küfrü lütfu hep imân olur

Hak katına elsiz ayaksız varır

Aşinâsız bir iş dürüst olamaz

Aşina gerekmiş Hakk'a yetmeye

Yorulmadan Hak'dan Hak'ka gitmeye

Kapusuz bacasız bir ev yapmaya

Meşrebsiz ol dört kapıdan varılmaz

Meşreb ile dört kapıdan girilür

Özün teslimle Allah'a varllır

Mürşidin önünde kefen sarllır

Cemiyette pirsiz namaz kulinmaz

Be a perfect man. He promises.

Have a kind belief. He shows the Way.

He finds his Way in front of the Truth.

You cannot find the genuine without Müsahip

You can find the genuine if you have müsahip.

Tribulation, abuse, grace... all become Iman

You reach the Truth without legs and hands

A work is not honest without them

You should be conscious for suffice the Truth

For going from the Truth to the Truth without being tired

For constructing the house without doors and flue

People cannot reach from the four doors without a sect (meşreb)

Yet people can access from four doors with a sect

People can access to Allah with their distribution

Believers embrace cerements in front of the Mürşid

[15]

Believers cannot pray to Allah without Pir [16]

\subsection{Müsahiplik Rituals of Alevisim and Bektashism}

It has been mentioned above, these written and oral sources are generally shared within Alevi communities in Turkey and Balkans. In order to be a member of Alevi community, there are two ways. First way is that those who must be born from Alevi father. In the past, we could find rare case of inter-marriage between Sunnis and Alevis. Then, we can explain that rituals practiced in the communities were just formally theoretical. Every child born from Alevi father or parents is considered to be a member of Alevi community so some Alevi religious ceremonies are open only for them. Secondly, those who declare and agree that they are ready for believe in the way of Muhammad and Ali are considered as a member of the Alevi community through the initiation ritual called Ikrar. The acceptance to the community comes true with these two kinds of membership [17].

Every Alevi community has a hierarchical relationship composed of Dede (Master) and Talip (Disciple). This relation is called Ocak in Turkish. It literally means household. Dede must be descended from the sacred family of the Prophet Muhammad called Ehl-i Beyt. Generally, disciples must be married and have müsahips. Müsahiplik named as "brotherhood of hereafter" or "brotherhood of the way" is one of the basic dispositions of the way of Alevism. These dispositions are strictly practiced. For instance, a disciple who doesn't have a müsahip cannot be allowed to attend an important ceremony like sacrifice. Therefore, he/she cannot share any sacrifice meets and meals [18].

The relationship of müsahiplik is tied between two males. If the men have been married, it included their wives. Even if this relationship is tied between two single men in some regions, it is essentially accepted as real müsahiplik when these two men get married. The majority of disciples generally choose to tie the müsahiplik after their marriage. These dispositions are so strict that they cannot easily apply for the agreement of the müsahiplik. Takips who want to apply for the participation of the ritual must swear that the relation continues both in this world and hereafter even each disciple dies. Disagreement is not permitted. Change of müsahip is not allowed. At the same time, müsahips are responsible for their families with each other both spiritually and materially forever. All the things which includes estates, sheep, foods, money etc. must be shared with each other [19].

This fictive kinship is more important than actual blood relation. If one müsahip transgresses one of the religious obligation, his partner must be automatically punished by dede. This practice is not in question if they are normal relatives based on blood kinship. While it is permitted for müsahips to marry with his/her cousins, the marriage of brothers or sisters of müsahips is considered as incest taboo. Religious guidebook of Alevism called Buyruk mentions that daughters müsahips cannot be a bride of the brothers of müsahips. It means that this fictive kinship is considered as brotherhood [20]. In this article, I try to describe how this fictive kinship is tied and accepted by the specific Alevi community through a ritual of Müsahiplik Cemi. Then I analyze the mechanism and function of solidarity of the Alevi community through ethnographic description conducted by the field research.

\subsection{Methodology}

"The notion that one can find the essence of national societies, civilizations, great religions, or whatever summed up and simplified in so-called "typical" small towns and villages is palpable nonsense. What one finds in small towns and villages is (alas) small-town or village 
life. If localized, microscopic studies were really dependent for their greater relevance upon such a premise-that they captured the great world in the little-they wouldn't have any relevance" [21].

This article is written by the ethnological method. The importance of ethnography has still been the essence within cultural and social anthropology nevertheless it tends to be despised in recent scientific world of anthropology. The problem is that the ethnography is written for whom. However, we cannot answer this question clearly. The reason why there is no human groups which can be automatically attributed to specific "society" or "culture" researched by anthropologists who conduct the field survey. The famous debate on the ethnic boundary researched by Frederic Barth has repeatedly exaggerated to localize on "personal" not on "groups" [22].

He continued to objectify the "image" of Bali where the anthropologists like Clifford Geertz and Margaret Mead describe in the field concerning Bali Island [23]. We don't have any information about whether these assertions have been practiced in the actual field research however, it doesn't mean to reveal the whole aspect of specific "society" or "culture" if an anthropologist describes the ethnography concerning a specific tribe or a specific village as Clifford Geertz mentioned above.

Though, at the beginning of a definite ethnographical debate, we avoidably have to restrict an "object" of research in some form or other. When we research an area, when we label the object, the problem is how to conduct the field research concerning what kinds of group of people, where the place is and when the time is. The method to resolve these problems is to describe the ethnography about "people (culture/society) in a specific area". Therefore, firstly we start to discuss on approximate restriction of a specific area to describe the ethnography.

\section{Fieldwork}

\section{1. Çorum Province and 1980 Incident}

Çorum province is situated in Central Anatolia (see the map below). Çorum is composed of 15 sub-provinces. Alevi villages in Çorum are wide spread out from the central to the south eastern region. We can find the Alevi villages indicated as red dots and the Sunni-Alevi mixed villages indicated as blue dots (see the Map below).

As I mentioned above, the correct census of religious affiliation does not exist however, it can be estimated that the population of Alevis in Çorum as 20 per cent of the total population of the province. According to my field research, there are Alevi villages in almost of all region of Çorum Province except for Oğuzlar sub-province (see the Table 1 below).

Half of total number of villages is Alevi villages in Central sub-province, Alaca sub-province, Mecitözü sub-province and Ortaköy sub-province. On the other hand, northern part of Çorum province has a few Alevi villages close to Çankırı, Kastamonu and Samsun provinces where the majority of population is conservative Sunni Muslims.

Table 1. Number of Alevi Villages in Çorum Province

\begin{tabular}{|c|c|c|}
\hline Sub-Provinces & $\begin{array}{c}\text { Number of Alevi } \\
\text { Villages }\end{array}$ & $\begin{array}{c}\text { Total Number of } \\
\text { Villages }\end{array}$ \\
\hline Alaca & 48 & 100 \\
\hline Bayat & 1 & 39 \\
\hline Boğazkale & 3 & 14 \\
\hline Dodurga & 2 & 12 \\
\hline İskilip & 7 & 64 \\
\hline Karg1 & 1 & 58 \\
\hline Laçin & 3 & 14 \\
\hline Mecitözü & 20 & 54 \\
\hline $\begin{array}{c}\text { Merkez } \\
(\text { Central })\end{array}$ & 91 & 201 \\
\hline Oğuzlar & 0 & 6 \\
\hline Ortaköye & 10 & 14 \\
\hline Osmancık & 7 & 56 \\
\hline Sungurlu & 20 & 112 \\
\hline Uğurludağ & 3 & 20 \\
\hline TOTAL & 216 & 764 \\
\hline
\end{tabular}

Throughout the history, Alevis have sometimes suffered the critic and sever persecution from conservative Sunni Muslims. Ottoman government divided people into Muslim and non-Muslim due to the difference of taxation system. At that time Muslims didn't have to pay tax for the government instead of military service. On the other hand, non-Muslims have to pay tax to the government. In this context, both Muslims and non-Muslims might be Monotheist included Christian and Jewish according to Shari'ah law. However, the position of Alevis was so ambiguous.

Sometimes they were considered as Muslim, sometimes were considered as non-Muslims. The worse thing was that they were considered as Pantheist or pagans. Nevertheless, the identity of the majority of them was Muslims, they don't go to the mosque for five times prayer per day for example. Moreover, they didn't practice Five pillar of Islam. In this case, it was possible to kill them according to Shari'ah law.

After the foundation of Turkish Republic, Shari'ah law court was removed from state political arena. Instead of Shari'ah law, the Republic is based on secular law so called Laiklik. At first, Alevis welcomed this secular Turkish Republic because it means the liberation from Islamic law for them however, the situation was not changed. The new Republic founded the Directorate of Religious Affairs in 1924 in order to control all the religions in this nation-state. This organization authorizes Islam, Christianity, Judaism, and so on. Concerning Islam, 
the Directorate of Religious Affairs offers religious services only based on the Sunni-Hanafi Islam. So that the Directorate of Religious Affairs makes the Alevism out of service. They regard it as one of the Islamic sects, not "official Islam". As a consequence, the position of Alevis continues to be ambiguous therefore, the discrimination against Alevis remains and accelerates up to 1980s in the Turkish society. Sometimes conflicts between Sunnis and Alevis come out in the Central and Eastern Anatolia where Sunnis and Alevis intimately live together. This discrimination has gradually begun to intensify the conflict between right and left wings since the beginning of the 1970s. At that time, conservative Sunni Muslims asserted themselves as "right wing". On the other hand, Alevis were labelled as "left wing".

The tension between Alevis and Sunnis has gradually risen since the late 1970s with the acceleration of collision of left wing and right wing groups in Turkey. At that time, the conflict between Alevis and Sunnis frequently occurred in Çorum. Before the incident, chief constable of Çorum Hasan Uyar was dismissed and former chief constable of Tunceli province Nail Bozkurt was appointed to replace to him. At the same time, Fahri Katar director of National Education was appointed. He was a member of Nationalist Action Party (Milliyetçi Hareket Pardisi/MHP).

Approximately forty police officer were transferred to other provinces and a lot of school teachers, officers and administrators were displaced to another positions. On the contrary to this change the majority of police officers continued their jobs at the same work place. This meant that police officers of sympathizer of MHP were collected to Çorum in order to control the activity of leftists and to suppress "leftist rebellions".

During the preparation for 19 May Youth and Sports Day in 1980, broachers were distributed. The slogan written on it was "Protect our girls under the name of honor of Islam! They are now under the danger! It is time to attack the demonstration of 19 May!" My informant narrated the situation of the process for the beginning of "Alevi massacre".

When I was a small boy... when I was 8 or 9 years old, one day I went to the mosque for Friday prayer with my father. At the end of the Friday Prayer at the Ulu Cami (Central mosque situated in the city center), people flocked to the exit. At the exit, I saw that a few men in suits was standing outside of the garden of Cami. I guessed they were from out of Çorum, I mean, they were not Çorum locals. Because Çorum is very small town so, we know with each other. Then, they suddenly shouted up, say, "Alevis are trying to destroy our Cami at Minarsinan District (10 km far from the Ulu Cami)!"

Then a riot began to attack on Alevi quarters everywhere in Çorum. Unofficial data shows that 126 Alevi citizens were killed in the incident at that time. Therefore, the people in always ask each other about their villages they are from or the quarter where they live at first meeting in order to confirm whether they are Alevis or Sunnis. In doing this, they try to prevent each other from hurting each other. Of course religious rituals of Alevis have been hide out from social arena for a long time due to Sunni persecution against Alevis. So it is hard to conduct the field survey especially in Çorum where the Çorum massacre has occurred. Both the Alevis and Sunnis are very sensitive concerning Alevism and their ritual.

\subsection{Cem Ritual and Müsahiplik Cemi}

It is hard to access to observe some Alevi ritual practices especially for yabancls (foreigners/strangers). The most representative Alevi ritual is Cem ceremony. According David Shankland's notion, Cem ceremony is collective prayer meeting of the Alevi community. It is at the same time the central ritual of Alevi religious life incorporating both men and women. The ceremony is practiced at Cemevi (Cem house) building constructed specifically to hold it growing in popularity among Alevi communities since the mid-1980s [24].

Cem ceremony is generally divided into two kinds. One is Birlik Cemi (Cem of the Union) which is open to non-Alevis included Sunnis as well as foreigners outside of the community. It includes the Kirklar Cemi (Cem of the Forty) which is took place every Thursdays at Cemevis and Nevruz Cemi (Cem of the Nevruz) celebrating the Spring Equinox [25].

The other is Görgü Cemi (Cem of the Grace) which is close for non-Alevis or foreigners. One of the most important proper conditions is to pass through the initiation ritual called Ikrar. Ikrar ritual means that a person choose the religious way of Alevi life (Alevi Yol Erkânı). This ritual is dependent on an individual, who must feel ready to be initiated - both psychologically and economically. The individual must make personal sacrifices. When an individual is initiated into Alevism, they belong to a specific religious group composed of Master-Disciple relation called ocak and are known as a disciple called talip [26].

It is not permitted to attend Görgü Cemi without Ikrar. Müsahiplik Cemi is one of Görgü Cemi. The ritual must be taken for Alevi people to make a müsahip relation. This Müsahiplik Cemi is one of the important rituals for Alevi people. All the participant must pass the İkrâr ritual before the attendance of Müsahiplik Cemi ritual [27].

I have conducted a field research in a village situated in the province of Çorum based on central sub-province. In this section I want to show you the criterion and detailed practice of müsahiplik ritual depending on data and source which I collected in the field research with the interview and observation [28].

The choice of Müsahip is dependent on the responsibility of each talip. In the actual field, there are no restrictions except for age and kinship through marriage. 
First, two Alevi man apply for a dede. They voluntary accept to be müsahip. They express their intention to dede. And then dede ask them the provision to be müsahip in front of witnesses. There are provisions to be müsahip below: firstly, candidates must NOT to be müsahip before. People can be müsahip only ONE time in his life. Second, candidates must to be adolescence age. Third, candidates must speak same languages. Forth, each candidate has same social status. Fifth, each candidate must have same educational level. Sixth, candidates must live same place. Seventh, (if he has a wife) each candidate's espouse must be müsahip. At the same time each espouses must understand themselves with each other. Eighth, each candidate must have no kinship relations.

If dede considers them appreciate to be müsahip, he takes them in front of him. Dede pray for the Truth standing at attention. And then dede tells them the obligations concerning the Müsahiplik. At the same time dede recite the dua (prayer) standing at attention.
Obligations of müsahips are below: first, müsahips have to help with each other until their death. Second, müsahips must not tell a lie and they must not eat something forbidden by Islam (haram lokma). Third, Eline, Diline, Beline Sahip olmak (Take responsibility for your words, actions, and morals), and finally, müsahips have responsibility of their mistakes with each other and they must put stay on a way to have guilty.

Then, dede wants to know whether this müsahiplik relationship is going on or not giving them a year. After this one-year process, müsahip candidates apply to dede to be müsahip again with their pleasure. This time Cem ritual is organized on Thursday night connected to holy Friday (Jum'ah). At that time if there are someone who wants to be müsahip, they participate in same Cem ritual at the same time. Generally, (if they have espoused) candidates of Müsahip participate in Cem ritual with espouses. They wear white cloths (Photo 1).

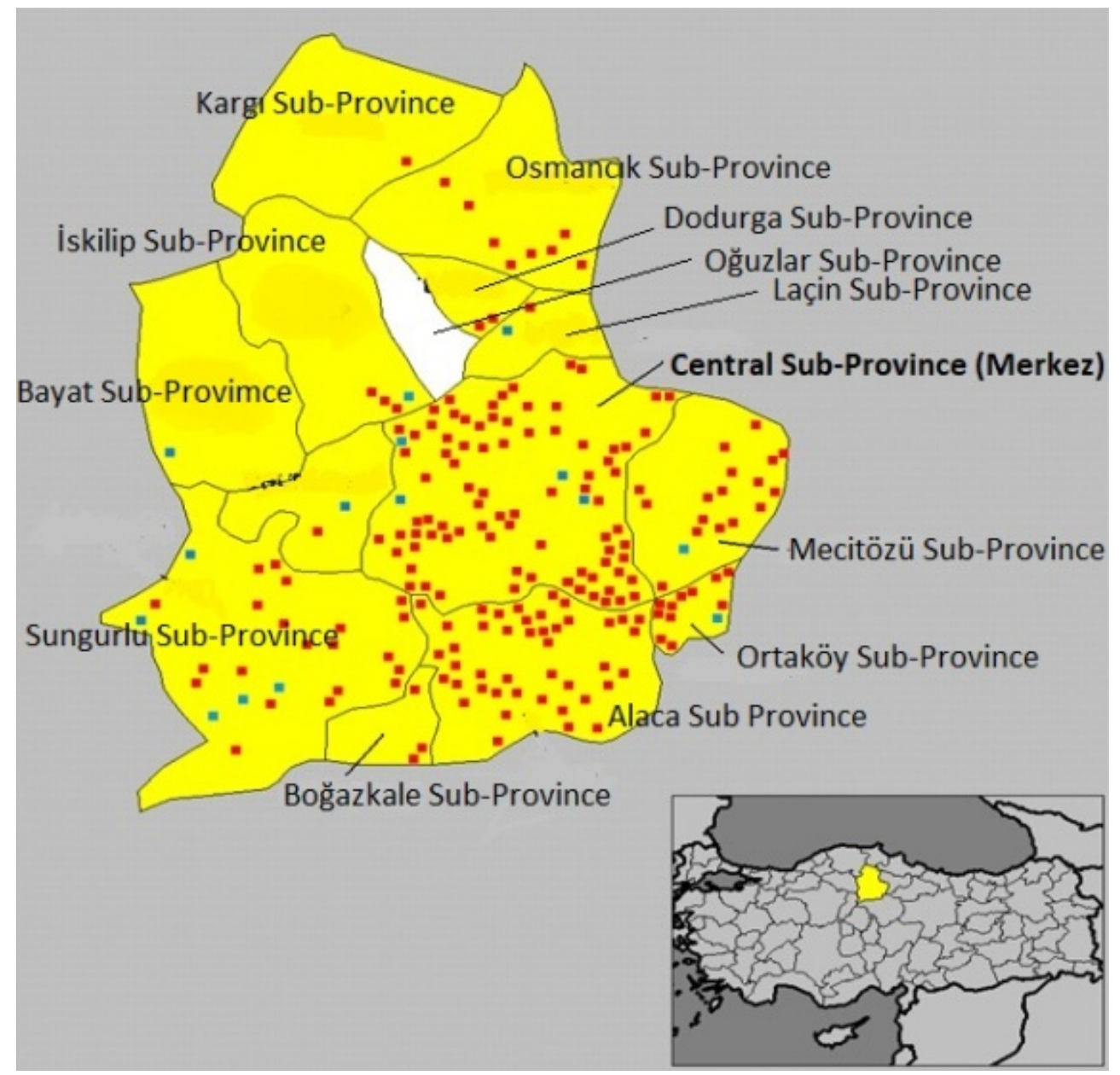

Figure 1. Map: Çorum and Alevi Villages 


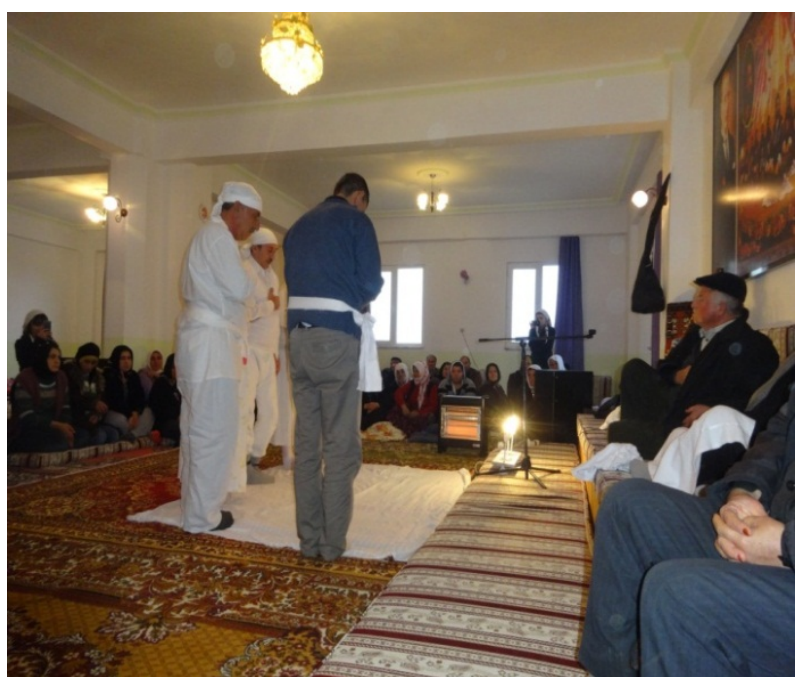

Photo 1. Müsahiplik Cemi (İkrâr Döşeği)

\section{The Ceremony of Müsahiplik Cemi and the Proposition}

As it can be understood from another usage of müsahiplik called "ahiret kardeşliği (Brotherhood of the Hereafter"), the true believers need to obtain the witness who can sanction what he/she did in this world and continue the relationship hereafter. Therefore, all Alevis have to find an associate who share the responsibility of their life both in the world and the hereafter before their death. The practice of Müsahip-connection is an important expression of the demand for the unity and togetherness of the community. At the beginning of the ceremony of the acceptance of Müsahiplik, applicants (two couples) say "Dört günül bir ettik, yola girmek istiyoruz! (We made our four souls unite, we want to enter the Way!)".

Then, müsahiplik ceremony strengthens the solidarity of the Alevi community and their identity. At the same time, this ceremony from the smallest social unit core family to whole Alevi community. The moral contents that are imposed to Müsahiplik is stronger and more restrictive than relativeness with blood kinship. Therefore, the tie which connected the community together provides guarantee against the danger of separation of the community. At the end, it can be crucially said that the tradition of müsahiplik contributes to create Alevi identity.

The place where the religious assembly is generally taken place is called "Meydan (arena)" in Alevism. On the other word, it is called "Ali'nin Meydanı (Ali's arena)". At the same time, the place where the müsahiplik cemi is taken place is called "eș meydanı (arena of spouse)" or "Müsahip meydanı (arena of Müsahip)" demonstrating the difference according to the regions. As with the all cem ceremonies, müsahiplik cemi also is taken place in an appropriate house, cemevi or the house of Dedes in the evening.
As with the other cem ceremonies, it must not be also forgotten that müsahiplik cemi is different according to regions and dedes. The procedure of the ceremony is different according to a number of participants and the level of the religious knowledge of each dede. In order to begin the ceremony, "On İki Hizmetçi (Twelve Servants)" must be ready in the Meydan. The number "Twelve" is symbolized as Twelver Imams in Shite Islam. The Twelve Servants are follow; Dede (Pir), Rehber (Guide), Gözcü (Observer), Çırağcı (Lamp Keeper), Kurbancı (Sacrificier), Zakir (Saz Player), Pervane (Cem Housekeeper), Süpürgeci (Broomer), Kuyucu (who embeds bones of sacrifice), Sâki (Water Server), İbrikçi (who is responsibility for water supply) and Sofrace (who is responsibility for dinner table). While these servants start the ritual, they accept the blessings of Dede.

After that the date was determined when to practice the ritual, Pervane was elected to invite disciples according to the opinion of Dede. Then, Dede selected the other servants among resourceful and experienced disciples. In the place where the ritual was practiced, people began to assemble since the evening. Participants might wear the most beautiful clothes at the ritual. Firstly, Dede entered into the house and sit by the hearth in the face of the door. Then the disciples entered into the house demonstrating respect to the threshold in order of age (they kissed pillar of the entrance of the house three times whispering "Allah, Muhammed Ali!"). Then they walked to Meydan in the room of the center and kissed Dede's right hand three times. And they turned behind the Meydan. Men sit in the front women sit in the back (Take a look at the photo 1, on the left side). Finally, the two couples wearing white cloths came into the Meydan in front of Dede with a sacrificial sheep.

A sheep carried by the candidates was set free to walk around the Meydan. Specific sign was expected that the sacrifice had been accepted by Allah on the Meydan. It is like sheep's urinary, cinder and tremble. All the cinders from the sheep must be embedded in the garden in front of the house. This is called "sir edilir (to make the secret)". After the sign, sheep was carried to outside the house and given to Kurbanc1 to be sacrificed and cooked. Then Dede blessed and prayed for Allah and Rehber keep a rope tied around the neck of the two couples. It is symbolized as the unity of the four candidates of Müsahip.

These Müsahip candidates can be müsahip with each other through müsahiplik cemi ritual. As I show on the center of Photo 1, you can find a white sheet sewn by wool on Meydan. This sheet is called "İkrâr Döşeği" (see the center of the Photo 1). It means "confession mattress" which symbolize the "death" and that means this müsahiplik relationship must be going on until their death. Before beginning of the ritual Dede try to reconcile all the participants who are stuffy with each other. Otherwise the ritual cannot be started.

While two couples lay down on the sheet, a man on the 
right side takes his right hand outside of the sheet and then he puts his right hand on dede's left shoulder. And then, he turns to a woman on the left side of the sheet, and she puts her left hand on dede's right shoulder. Dede connects their (two couples') arms with each other. It is called "şehadet parma ğ $l$ (confession fingers)" under the name of Twelver Imams. At the same time, they are symbolized as Prophet Muhammed, Ali, Hasan and Husain.

If he or she abandons the müsahiplik relation no one can make him or her müsahip. They can never be müsahip. Even if he or she dies and he or she wants to be müsahip, they have no right to be müsahip. However, if the case of death of espouse and he or she intends to be müsahip again, he or she has müsahip give "kurban (sacrifice)" to dede and all participants of Cem ritual. In the end of the ritual sacrifices were shared by all participants and water with Dede's blessing was sprinkled on the head of them. Therefore, the two couples were accepted as Müsahip by all the community.

\section{Conclusions}

As Marshal Sahlins mentions in her comprehensive work on social kinship, kinship is not given by birth as such, since human birth is not pre-discursive fact (Sahlins 2013: 3).

Now müsahiplik relationship has revived for last two decades. It is a true situation that the traditions depending on an oral source has been changed during the huge social change like globalization. We anthropologists must evaluate and observe an oral tradition as more functional matter. Traditions are no longer shared by limited group (like dede or religious authority). Printed media published by academia and dedes can be accessible for all people. All of information concerning Alevism and their ritual practices are shared by all of us even if these knowledges are not "true".

On the other hand, we have to consider another important fictive kinship called kirvelik for Alevi people. Kirve is the man, who holds in his lap the boy being circumcised, resulting in an alliance between the two families, and for several generations family members are forbidden from marrying each other. This institution is particularly widespread among Kizilbas/Alevis but is not exclusive to them. Müsahiplik and Kirvelik must be scarcely differentiated but they are important fictive kinship in the Alevi community in Turkey.

\section{Acknowledgements}

We are very grateful to experts for their appropriate and constructive suggestions to improve this template.

\section{REFERENCES}

[1] M. H. Yavuz, "Media Identities for Alevis and Kurds in Turkey," D. F. Eickelman \& J. W. Anderson (eds.), New Media in the Muslim World: The Emerging Public Sphere, Bloomington \& Indianapolis: Indiana University Press, 180-183, 1999.

[2] K. Vorhoff "Academic and Journalistic Publications on the Alevi and Bektashi of Turkey," Tord Olsson, Elisabeth Özclalga and Catharina Raudvere (eds.), Alevi Identity: Cultural, Social and Religious Perspectives, Istanbul: Swedish Research Institute of Istanbul, 1998: 23

[3] D. Shankland, The Alevis in Turkey: The Emergence of Secular Islamic Tradition, London: RoutledgeCurson, 2006: 81)

[4] Ibid.

[5] H. Wakamatsu, "Transmitting the tradition: An analysis on master-disciple relationship in Alevi community of Turkey." International Journal of Social Sciences and Education Research, 1 (3), 642.

[6] İ. Kaygusuz, Müsahiplik, İstanbul: Alev Yayınları. 2008: $14-15$.

[7] K. Kehl-Bodrogi Die Kızılbaş-Alevitum: Untersuchungen über eine esoterische Glaubensgemeinschaft in Anatolien, Berlin: Schwarz, 1988: 115-116

[8] A. Yalçınkaya Alevilikte Toplumsal Kurumlar ve İktidar, Ankara: Mülkiyeliler Birliği Yayınları, 1996.

[9] I. Mélikoff Hadji Bektach: un mythe et ses avatars, Leiden: Brill, 1998: 210-215.

[10] M. Eröz, Türkiye'de Alevilik Bektaşilik, Ankara: Kültür ve Turizm Bakanllı̆ı, 1990, 110-111.

[11] Primarily Öztelli's work, we can find a lot of books concerning müsahiplik tradition published by Alevi cultural associations. (C. Öztelli, Pir Sultan Abdal, İstanbul: Milliyet Yayınları 1973: 239).

[12] The concept of dört kapı kırk makam (four doors and forty posts) is the concept of tasavvuf (Sufism). To a lesser extent in other branches of Islam such as Ismailism and Alevism, that there are four paths to Allah, starting with shari'a, then to tariqah, then to ma'rifah and finally to haqiqah (the Truth). Each path has ten posts.

[13] Pir is a title for a Sufi master or spiritual guide used in the tradition.

[14] K. Kehl-Bodrogi Die Kızllbaş-Alevitum: Untersuchungen über eine esoterische Glaubensgemeinschaft in Anatolien, Berlin: Schwarz, 1988: 164-165.

[15] Mürşid is Arabic for "guide" or "teacher", derived from the root $\mathrm{r}$-ş-d, with the basic meaning of having integrity, being sensible, mature.)

[16] For more detail see Ergün's work (Ergün 1956: 85). In this nefes Şah İsmail Hatayi mentioned that people cannot pray for Allah (Ibada) without Pir.

[17] K. Kehl-Bodrogi, Kızılbaşlar/Aleviler, İstanbul: Ayrıntı Yayınları, 2012: 150. 
[18] Ibid.

[19] K. Kehl-Bodrogi, Op. Cit., 150-151.

[20] S. Aytekin, Buyruk, İstanbul: Ayyıldız Yayınları, 2001: 195.

[21] C. Geertz, The Interpretation of Cultures: Selected Essays Clifford Geertz, New York: Basic Books Inc., Punlisher, 2006 (1973): 22.

[22] F. Barth, Ethnic Groups and Boundaries: The Social Organization of Cultural Difference, Boston: Brown Company, 1969.

[23] F. Barth, Principles of Social Organizations in Southern Kurdistan, New York: AMS Press, 1979.

[24] D. Shankland, The Alevis in Turkey: The Emergence of a Secular Islamic Tradition, London: Routledge, 2003: 187.

[25] Concerning the detailed information about Nevruz Cemi ceremony, see H. Wakamatsu, "The Present day Nevruz Festival in Turkey: From Celebration of the Equinox to a Battlefield of Ethnicity," Annals of Japan Association for Middle East Studies, 24(2), 29-59.

[26] Ikrâr ceremony is taken for entering into the Alevi yol erkânı (Alevi religious path to the Truth). People cannot be an Alevi without İkrâr.

[27] S. K. KILIÇ, "Initiation (İkrar) Cem Ritual of the Surek of Çamlıca in the Seyit Ali Sultan Ocak, " Türk Kültürü ve Hacı Bektaş Veli Araştırma Dergisi, 2014, 71: 35-37.

[28] I conducted my field research in a village of Merkez sub-province in Çorum province, central Anatolia on March 2015 supported by BAP (Science Research Project) of Hitit University/TURKEY.

\footnotetext{
$\mathrm{i}$ This article is the revised version of a paper presented at the 20th Congress of the European Anthropological Association held in Zagreb 24-28 August 2016.
} 